\title{
IPTEKS PROSES PENGELOLAAN LAPORAN KEUANGAN PADA BADAN PERENCANAAN PEMBANGUNAN PENELITIAN DAN PENGEMBANGAN DAERAH (BAPELITBANGDA) KOTA MANADO
}

\author{
Clarissa B. Rondonuwu ${ }^{1}$, Wulan D. Kindangen ${ }^{2}$ \\ ${ }^{1,2}$ Jurusan Akuntansi, Fakultas Ekonomi dan Bisnis, Universitas Sam Ratulangi, Kampus Unsrat, Sulawesi \\ Utara, 95115, Indonesia \\ Email : clarissarondonuwu@gmail.com
}

\begin{abstract}
The Manado City Planning, Development, Research and Development Agency (BAPELITBANGDA) is an agency or institution that assists the Mayor in supporting everything related to Planning, Development, Research, Development, and under the leadership of the head of the agency. The purpose of this study is that we can find out the process of managing financial statements from the Planning, Development, Research and Development Agency of the City of Manado. Because in each activity or program implemented requires funds to support the smooth running of the planned activities. Therefore, financial statements are very necessary for an institution because it is very useful in assessing a financial condition in all activities carried out. Thus, the applicable accounting principles are needed, so that the financial report management process can run well and efficiently.
\end{abstract}

Keywords: financial report management process, BAPELITBANGDA Manado City

\section{PENDAHULUAN}

Untuk dapat menyediakan informasi mengenai suatu posisi keuangan dan seluruh transaksi yang ada selama satu periode pelaporan yang sangat dipercaya dan relevan, maka disusunlah Laporan Keuangan. Tujuan dilakukannya laporan keuangan adalah untuk menyajikan informasi mengenai posisi keuangan, kinerja keuangan suatu pelaporan dalam mengerjakan dan mengevalusi keputusan mengenai alokasi sumbr daya. Sesuai dengan peraturan yang dibuat oleh pemerintah maka, dalam setiap substansi memiliki kewajiban dan tanggungjawab dalam membuat atau mengerjakan suatu laporan keuangan. Oleh sebab itu, laporan keuangan harus disusun atau dibuat dengan baik, benar dan dengan menggunakan prinsip-prinsip akuntansi yang masih berjalan, agar supaya proses pengelolaan laporan keuangan dapat berjalan dengan sangat baik dan efesien serta memudahkan banyak pihak. Laporan keungan sangat berguna dalam menilai kondisi keuangan, membandingkan realisasi pendaptan, belanja dan transfer dalam seluruh kegiatan yang dilaksanakan dalam suatu organisasi. Dalam Pemerintah, laporan keuangan berguna menyiapkan informasi yang sangat dipercaya atau akurat tentang kinerja, posisi keuangan maupun perubahan dari posisi keuangan suatu organisasi.

\section{TINJAUAN PUSTAKA}

Komponen Proses Pengelolaan Laporan Keuangan. Dalam pengelolaan keuangan diperlukan prinsip-prinsip untuk mengontrol suatu kebijakan daerah, meliputi: Akuntabilitas, Kejujuran dalam mengelola keuangan public, Value for money, Pengendalian dan Transparansi.

Akuntabiltas adalah sebuah pertanggungjawaban seseorang atau institusi yang berkaitan dengan administrasi public dalam menggunakan dana yang bukan milik sendiri secara baik, ekonomis, tidak ada korupsi dan yang dapat dipercaya. 
Kejujuran Dalam Mengelola Keuangan Publik. Dalam sebuah organisasi atau lembaga kejujuran merupakan hal yang sangat penting dalam mencapai suatu tujuan, terutama dalam bidang keuangan. Dimana, untuk mengelola keuangan memerlukan seseorang yang dapat dipercaya, memiliki kejujuran yang tinggi dan memiliki kepribadian yang baik. Sehingga mampu mempertanggungjawabkan apa yang menjadi tugasnya dan bias mengurangi kesempatan untuk melakukan tindakan korupsi.

Value For Money adalah sebuah konsep dalam mengelola organisasi maupun mengukur suatu kinerja dalam sector public dan berdasar pada Ekonomi, Efesiensi dan Efektifitas yang merupkan tiga elemen dari konsep pengelolaan organisasi.

Pengendalian adalah proses dalam mengatur berbagai masalah suatu lembaga atau organisasi, agar setiap program atau rencana yang akan dilaksanakan dapat terlaksana dan tercapai sesuai tujuan yang akan dicapai.

Transparansi adalah suatu tindakan terbuka, nyata, jelas atau tidak tertutup atas semua tindakan dan strategi yang dibuat oleh pemerintah. Dimana dalam pemerintahan kita dapat mengetahui atau memperoleh informasi yang akurat dan sesuai keinginan dengan mudah.

\section{METODE DAN TEKNIK PENERAPAN IPTEKS}

\subsection{Metode Penerapan Ipteks}

Metode Ipteks yang diterapkan adalah Prinsip-prinsip pengelolaan keuangan yang sangat diperlukan untuk mengawasi kebijakan suatu keuangan daerah.

\subsection{Teknik Penerapan Ipteks}

Teknik Ipteks yang diterapkan adalah prinsi-prinsip pengelolaan laporan keuangan, yakni: Akuntabilitas, kejujuran dalam mengelola keuangan public, Value for money, Pengendalian dan Transparansi.

\section{PEMBAHASAN}

\subsection{Gambaran Objek Proses Pelaporan}

Pada tanggal 2 Oktober 1998 Badan Perencanaan, Penelitian dan Pembangunan Daerah Kota Manado atau yang sering disebut BAPEDA di Negara Republik Indonesia didirikan oleh akta notaris Sutjipo, S.H, No.10, dengan berdasarkan pada peraturan Pemerintah No. 75 tagun 1998 tanggal 1 Oktober. Pada akhir tahun 2016, BAPPEDA Kota Manado berubah menjadi Badan Perncanaan Pembangunan, Penelitian dan Pengembangan Daerah Kota Manado atau yang sering disebut BAPPELITBANGDA menurut Peraturan Walikota Manado Nomor 59 Tahun 2016 mengenai Kedudkan, Susunan suatu Organisasi dan Tata Kerja serta Rincian Tugas dan Fungsi Badan Perencanaan, Penelitian, Pengembangan Daerah Kota Manado. Untuk membantu Pemerintah Daerah dalam memenuhi kebutuhan, pertkembangan dan kemajuan dibidang pemerintahan maupun kemajuan teknologi serta untuk membantu dalam melaksanakan pembangunan, khususnya dibidang pemeringtahan maka perlu dibentuknya Badan Perencanan Pembangunan Daerah. Adapun Fungsi dari Badan Perencanaan Pembangunan Penelitian dan Pengembangan Daerah Kota Manado, yaitu: Menyusun kebijakan teknis, melaksanakan tugas dukungan dan fungsi lain, melaksanakan evaluasi dan pelaporan pelaksanaantugas, dan melakuan pembinaan teknis penyelangaraan fungsi penunjang urusan pemerintahan, semuanya berdasarkan pada lingkup tugasnya.

\subsection{Pembahasan}

Dalam Proses Pengelolaan Keuangan diperlukan proses untuk mengontrol kebijakan keuangan daerah, antara lain:

1. Akuntabilitas. Akuntabilitas mewajibkan bahwa dalam mengambil suatu keputusan sebaiknya berperilaku sesuai dengan perintah atau arahan yang telah diterapkan. Karena dalam suatu organisasi harus dapat menguraikan apapun keputusan atau tindakan yang 
mereka ambil dan mampu mepertanggungjawabkan. Untuk itu, agar dapat mencapai suatu keberhasilan atas kebijakan yang dihasilkan, kebijakan tersebut harus dapat dikomunikasikan secara dengan baik dan dapat diakses.

2. Kejujuran dalam mengelola keuangan publik. Sampai saat ini, masih banyak suatu lembaga menyalahgunakan kekuasaan, birokrasi, pemerintahan, dll untuk melakukan penyelewengan atau penyalagunaan uang negara untuk keuntungan atau kebahagiaan pribadi. Oleh karena itu, dalam mengelola keuangan harus memiliki seseorang atau staf yang sangat dipercaya dan memiliki integritas, professesional, serta kejujuran. Sehingga, peluang untuk menyalahguakan uang negara atau yang biasa kita kenal dengan sebutan Korupsi dapat diminimalkan.

3. Value For Money. Sektor publik sekarang ini acap kali dinilai sebagai tempat atau sarang ketidakefisienan, pemborosan dan lembaga yang selalu mendapat rugi. Namun, dengan konsep Value for money dipercayakan dapat memperbaiki kinerja dan memperbaikan akuntabilitas sector public. Seperti, menigkatnya kesejahteraan dan pelayanan masyarakat, meningkatnya kesadaran terhadap uang yang bukan milik sendiri melainkan milik public, serta alokasi belanja lebih cenderung mengutamakan pada kepentingan public. Value for money akan dapat terlaksana jika suatu organisasi mampu berkomitmen dan sadar akan hak dan kewajiaban dari tugasnya masing-masing untuk mendukung terlaksananya value for money.

4. Pengendalian. Anggaran Pendapatan dan Belanja Daerah yang disingkat dengan APBD wajib dipantau,diamati dan dikontrol, untuk membandingkan antara yang akan dicapai dengan yang dianggarkan. Agar supaya dapat mengetahui penyebab timbulnya varianss dan untuk kedepannya dilakukan tindakan antisipasi, maka perlu dilakukan analisis terhadap pendapatan serta belanja daerah.

5. Transparansi. Transparansi adalah suatu hal yang tidak disembunyikan atau tidak ada maksud tersembuyi, jelas, nyata, terbuka, dan dapat dipertanggungjawabkan. Dalam mengelola keuangan sangat diperlukan dan diwajibkan prinsip Transparansi seperti ini. Dalam mengelola keuangan mempunyai resiko yang sangat besar bagi lembaga public atau institus. oleh karena itu, perlunya Transparansi yang merupakan suatu hal yang sangat penting untuk dilakukan. Agar terciptanya pemerintah daerah yang akuntabel, efektiif, efesien, dan responsive terhadap aspirasi serta kepentingan masyarakat, maka horizontal accountability harus terwujud oleh pengelolaan keuangan daerah anatara pemerintah dengan massyarakat.

\section{KESIMPULAN DAN SARAN}

\subsection{Kesimpulan}

Proses pengelolan laporan keuangan pada Badan Perencanaan, Pembangunan, Penelitian dan Pengembangan Daerah Kota Manado akan berjalan dengan baik, efesien, dan tepat sasaran apabila jika point-point yang ada pada prinsip-prinsip pengelolaan laporan keuangan, yaitu: Akuntabilitas, Kejujuran dalam mengelolaa keuangan, Value for money, Prngendalian, dan Transparansi telah dilaksanakan dengan baik dan benar.

\subsection{Saran}

Dalam melaksanakan pengelolaan laporan keuangan, BAPELITBANGDA Kota Manado telah menjalankan tugasnya masing-masing sesuai peraturan pemerintahan dengan baik. Sebaiknya, terus mempertahankan apa yang baik dan terus mengikuti peraturan yang ada, agar berjalan dengan baik. 


\section{DAFTAR PUSTAKA}

http://bapelitbang.manadokota.go.id/

Dahlia, D. (2014, Juni). Analisis Pengelolaan Dan Pelaporan Keuangan Pada Satuan Kerja Bidang Keuangan Polda Sulawesi Utara. Jurnal EMBA, 2(2). Universitas Sam Ratulangi. Manado

Hartoko, Alfa. 2011. Menyusun Laporan Keuangan untuk Usaha. Yogyakarta: Multicom

Halim, Abdul. 2012. Akuntansi Sektor Publik Akuntansi Keuangan Daerah Edisi 4. Jakarta: Selemba Empat

Hendry, A. (2013, September). Analisis Laporan Keuangan Dalam Mengukur Kinerja Keuangan Pada PT. Hanjaya Mandala Sampoerna TBK. Jurnal EMBA Vol. 1 No. 3. Universitas Sam Ratulangi. Manado

Hery. 2016. Analisis Laporan Keuangan. Jakarta: Gramedia

Kariyoto. 2017. Analisa Laporan Keuangan. Malang: Perguruan Tinggi Terbaik dan Terbesar Kelas Dunia

Peraturan Menteri Dalam Negeri Nomor 59 Tahun 2007. 2011. Pedoman Pengelolaan Keuangan Daerah. Bandung: Fokusmedia

Peraturan Pemerintah RI Nomor 71 Tahun 2010. 'Tanpa Tahun'. Standar Akuntansi Pemerintahan. Jakarta Selatan: Selemba Empat

Prastowo, Dwi. 2011. Analisis Laporan Keuangan Edisi Ketiga. Yogyakarta: Unit Penerbit dan Percetakan

Restianto, Yanuar. 2010. Pengelolaan Keuangan Daerah. Jakarta: Selemba Empat

Sulistiyowati, Leny. 2010. Memahami Laporan Keuangan. Jakarta: PT. Elex Media Kamputindo 